\title{
ANÁLISE DE ALGUMAS DISPOSIÇÕES DO CÓDIGO DE PROCESSO DOS TRIBUNAIS ADMINISTRATIVOS À LUZ DA LEI DA ARBITRAGEM - BREVES QUESTÕES
}

\author{
Francisco Calvão \\ fcalvao@jurisprt.com \\ Paulo da Cunha Monteiro \\ pmonteiro@jurisprt.com
}

\section{NOTA PRÉVIA}

As presentes anotações constituem uma breve incursão pelas disposições do Título IX -- Tribunal Arbitral e centros de arbitragem - do Código de Processo dos Tribunais Administrativos ${ }^{1}$, numa análise conjugada com a Lei da Arbitragem Voluntária ${ }^{2}$. Pretendemos apenas contribuir para a discussão deste tema, suscitando algumas questões que em nosso entender assumem considerável relevo prático no plano do direito adjectivo administrativo.

Embora o CPTA estabeleça o essencial do regime jurídico da arbitragem no contexto do direito administrativo, há aspectos que ficam por definir; por essa razão, o próprio Código ora remete genericamente para a lei ( «nos termos da lei» - cfr. art. 182. $)$, ora determina a aplicação da «lei sobre arbitragem voluntária, com as devidas adaptações» (cfr. arts. $181 .^{\circ}$ e $186 .^{\circ}$ ). Como não existe qualquer diploma legislativo de direito administrativo a regular esta matéria, o legislador só pode ter aqui em vista a $\mathrm{LAV}^{3}$. A referência à necessidade de proceder às

1 Aprovado pela Lei $15 / 2002$, de 22 de Fevereiro, posteriormente alterado pela Lei 4-A/2003, de 19 de Fevereiro - de agora em diante designado por CPTA.

${ }^{2}$ Aprovada pela Lei 31/86, de 29 de Agosto - de agora em diante designada por LAV.

${ }^{3}$ No mesmo sentido, José Carlos Vieira de Avidrade, A Justiça Administrativa, 8. ed., 2006, pág. 147. 
«devidas adaptações» e o ajustamento levado a cabo no $n .{ }^{\circ} 2$ do art. $186 .^{\circ}$ só vem reforçar este entendimento, pois tais menções não teriam razão de ser caso o legislador pretendesse referir-se a uma lei futura que regulamentasse os aspectos omissos da arbitragem de conflitos jurídico-administrativos ${ }^{4}$.

Assim, começaremos por apresentar de modo sucinto a LAV e os aspectos nela regulados que directamente relevam para arbitragem voluntária nas relações de direito administrativo, para só depois nos concentrarmos no CPTA e nos preceitos que mais dúvidas nos têm suscitado.

\section{O TRIBUNAL ARBITRAL E A LEI DA ARBITRAGEM VOLUNTÁRIA: BREVE INTRODUÇÃO}

\section{O tribunal arbitral e sua natureza}

No ordenamento jurídico português, a disciplina geral da arbitragem voluntária encontrava-se consagrada nos artigos $1561 .^{\circ}$ e segs. do Código de Processo Civil de 1939 e arts. $1508 .^{\circ}$ e segs. do Código de Processo Civil de 1961.

Hoje, tal disciplina está regulada na Lei n. ${ }^{0} 31 / 86$, de 29 de Agosto (Lei da Arbitragem Voluntária), cuja aprovação assentou na Proposta de Lei ${ }^{\circ}{ }^{\circ} 34 / \mathrm{IV}$, e que no fundo acompanhou as reformas legislativas que foram ocorrendo em alguns países da Europa, designadamente na Grécia, França, Bélgica, Espanha e Reino Unido. Sobretudo, este diploma veio concretizar ou materializar a norma da Constituição da República Portuguesa que, desde a revisão constitucional de 1982 (cfr. n. ${ }^{\circ} 2$ do art. $212 .^{\circ}$, actual n. ${ }^{\circ} 2$ do art. $209 .^{\circ}$ ), prevê a possibilidade de constituição de tribunais arbitrais.

Em traços gerais, a LAV veio permitir às partes submeter qualquer litígio à decisão de árbitro ou árbitros, desde que por lei especial aquele não esteja reservado a um tribunal judicial ou à arbitragem necessária e não colida com direitos indisponiveis, como decorre do seu artigo $1 .{ }^{\circ}$, sob a epígrafe Convenção de Arbitragem. Esta mais não é do que a manifestação concordante de vontades pela qual as partes confiam à de-

\footnotetext{
${ }^{4}$ A este ponto voltaremos infra, quando analisarmos especificamente o disposto no art. 182. do CPTA.
} 
cisão de árbitro(s) um litígio actual ou eventual litígio futuro emergente de determinada relação jurídica, promovendo, para o efeito, as diligências necessárias à constituição do tribunal arbitral - nesta medida, tal convenção constitui um negócio jurídico bilatera $1^{5}$.

Percebe-se, assim, que a LAV, alicerçada no princípio da autonomia privada, atribua especial relevo à vontade das partes na determinação do tribunal competente para dirimir os seus litígios, respeitando os seus interesses. Por essa razão, há até quem qualifique as convenções de arbitragem como «contratos processuais» ${ }^{6}$. $\mathrm{O}$ tribunal arbitral nasce, de facto, para dirimir um conflito determinado pelas partes, vendo a sua competência para o caso concreto dependente da vontade destas expressa na convenção de arbitragem.

E porque a sua constituição emerge da vontade das partes, os tribunais arbitrais voluntários são considerados instituições de natureza privada, não obstante as decisões arbitrais preencherem também uma função pública. É que a arbitragem representa uma via alternativa de resolução dos litígios paralela à da jurisdição comum ou dos tribunais judiciais, cuja intervenção não pressupõe o acordo das partes, ao contrário do que sucede com aquela, que somente funciona nos casos em que é legalmente admitida e quando estas acordam na sua constituição. Como refere Raul Ventura a "convenção é adjectiva relativamente à relação jurídica a que respeita. Não afecta directamente essa relação jurídica, seja ela de que natureza for; não modifica o seu conteúdo, pois é lhe exterior, embora envolvente. Nem sequer pode ter sobre uma relação jurídica o efeito jurídico eventualmente resultante duma correspondente relação processual, pois a convenção de arbitragem não soluciona nem pretende solucionar o litígio, mas apenas providenciar sobre meios de solução».

Precisamente por participarem no exercício da função jurisdicional, os tribunais arbitrais emitem decisões a que a ordem jurídica reconhece força de caso julgado e de título executivo, possuindo valor jurídico de uma sentença de primeira instância (cfr. art. $26{ }^{\circ}$ da LAV) ${ }^{8}$.

\footnotetext{
${ }^{5}$ Ac. STJ de 18.01.2000, in BMJ 493. ${ }^{\circ}$, págs. 327 e segs.

${ }^{6}$ Miguel Teixeira de Solsa, A Competencia Declarativa dos Tribunais Comuns, 1994, pág. 100 .

${ }^{7}$ Rall Vertura, Convenção de Arbitragem, in R.O.A, Ano 46, 1986, II, págs. 298 e 299.

${ }^{8}$ Os tribunais arbitrais apenas têm competência declarativa, já que a execução da sentença arbitral é da competência dos tribunais judiciais.
} 
Em suma, e aproveitando as palavras de Francisco Cortez ${ }^{9}$, «a arbitragem voluntária é contratual na sua origem, privada na sua natureza, jurisdicional na sua função e pública no seu resultado».

\section{Vantagens da arbitragem}

Pode afirmar-se que o recurso à arbitragem confere às partes relevantes vantagens para a prolação de uma decisão ${ }^{10}$. Das quais se destacam a celeridade e a especialização. O generalizado atraso na tramitação dos processos afectos à justiça administrativa, provocado fundamentalmente pela insuficiência de magistrados e funcionários, é um «hábito» para o qual não parece haver, no imediato, uma solução eficaz, o que provoca prejuízo directo aos litigantes (ou, pelo menos, a um deles); sendo certo que estes cada vez mais vêm exigindo maior celeridade na tramitação processual, acompanhando de resto a tendência da sociedade em geral. Ao contrário do que sucede na jurisdição administrativa, a jurisdição arbitral fornece uma decisão final célere, celeridade essa explicada pelas seguintes circunstâncias: o prazo para ser proferida decisão é, em regra, de seis meses, os árbitros têm a seu cargo um número reduzido de processos, estão previstas penalizações para aqueles pelo incumprimento dos prazos, e pressupõe que exista uma maior simplificação processual.

Por outro lado, o tribunal arbitral é uma alternativa válida para julgar questões que reclamam conhecimentos específicos ou técnicos que não estão ao alcance de um julgador normal, ainda para mais quando se pretende a resolução de um litígio dentro de um prazo razoável. Acresce que, desse modo, se potencializa a confiança das partes, pois cada uma pode indicar o seu árbitro.

Por último, este tribunal pode assegurar um grau de confidencialidade ao litígio que as audiências dos tribunais estaduais não permitem, resguardando assim a imagem dos litigantes junto de concorrentes e/ou do público-consumidor ${ }^{11}$.

\footnotetext{
${ }^{9}$ A Arbitragem Voluntária em Portugal, in O Direito, ano 124. IV. 1992, pág. 555.

10 Sobre o ponto, vide JOÃO CALPERS, A arbitragem nos litígios entre a administração pública e os particulares, in Cadernos de Justiça Administrativa (CJA), n. ${ }^{\circ} 18$, págs. 6 e 7 . 11 Neste sentido, Miguel TejXeira de Sousa, O Direito, ano 120.․ III-IV, 1988, pág. 567.
} 


\section{A Lei da Arbitragem Voluntária}

Sem pretendermos proceder a uma análise pormenorizada da LAV, destacamos neste ponto dois ou três aspectos mais relevantes para as considerações que em seguida se fazem.

Em primeiro lugar, note-se que o artigo $1 .^{\circ}$ deste diploma distingue entre compromisso arbitral, aquele que tem por objecto um litígio actual, ainda que eventualmente se encontre confiado a um tribunal judicial, e cláusula compromissória, reportada a litígios futuros e incertos emergentes de uma determinada relação jurídica (pré)contratual ou extracontratual.

Cumpre também registar o facto de a convenção de arbitragem ser necessariamente reduzida a escrito - cfr. n. ${ }^{\circ} 1$ do art. $2 .^{\circ}$ da LAV - e a particularidade de no n. ${ }^{\circ} 2$ deste artigo se considerar haver vinculação ao tribunal desde que haja um qualquer documento assinado pelas partes, ou tal resulte da troca de cartas, telex, telegramas ou outro meio de telecomunicações de que fique prova escrita (telecópia ou e-mail).

No que respeita ao modo de funcionamento da arbitragem, as partes têm autonomia na determinação do conteúdo do compromisso arbitral, tendo por isso liberdade para definir os aspectos que neste pretendem ver incluídos, designadamente, número de árbitros - art. $7 .^{\circ}, \mathrm{n}^{\circ} 1-$, o modo da sua designação - art. $14 .^{\circ}$, n. ${ }^{\circ} 1-$, regras de processo e sede da arbitragem - art. $15 .^{\circ}-$, prazo para a decisão - art. $19 .^{\circ},{ }^{\circ} .^{\circ} 1$, poderes dos árbitros - arts. $22 .^{\circ}$ e $23 .^{\circ}$-, direito a aplicar - art. 33. n. ${ }^{\circ} 1$-, quanto à decisão, exigindo maioria qualificada ou autorizando a decisão no sentido de voto do presidente - art. $2 .^{\circ}$, n. ${ }^{\circ} 1$ e $2-$ e, por último, renúncia antecipada aos recursos - art. 29..

\section{A ARBITRAGEM DE LITÍGIOS EMERGENTES DE RELAÇÕES JURÍDICAS ADMINISTRATIVAS}

Consideremos agora as principais regras que fixam o regime geral da arbitragem no contexto de relações jurídico-administrativas, e que vêm previstas no CPTA. Começaremos pela análise das questões de direito administrativo susceptíveis de constituir objecto de arbitragem voluntária. 


\section{Delimitação das questões jurídico-administrativas que podem ser dirimidas por um tribunal arbitral}

O CPTA enuncia, no seu art. $1800^{\circ}$, os conflitos susceptíveis de serem dirimidos pelos tribunais arbitrais; mas, como veremos, o âmbito de matérias que eventualmente poderão ser submetidos à apreciação de um tribunal arbitral é muito mais abrangente do que as três situações insitas naquela disposição.

Com efeito, o CPTA, salvaguardando ainda outras hipóteses previstas em lei especial, reserva a possibilidade de constituição de um tribunal arbitral para dirimir conflitos que respeitem a:

a) Contratos, incluindo a apreciação de actos administrativos relativos à respectiva execução ${ }^{12}$ - ou seja, as questões enunciadas nas alíneas b), e) e f) do art. $4 .^{\circ}$ do Estatuto dos Tribunais Administrativos e Fiscais (ETAF) e tudo o que se relacione com a execução dos contratos.

Assim, por aplicação da alínea b) do art. $4 .^{\circ}$ do ETAF serão objecto de decisão arbitral a invalidade de contratos de qualquer natureza (pública ou privada) celebrados por qualquer pessoa (pública ou privada), desde que a ilegalidade contratual decorra da invalidade de um acto administrativo com base no qual aquele tenha sido celebrado ${ }^{13}$.

Da alínea e) do mesmo preceito resulta estar submetida à arbitragem qualquer questão relativa à interpretação, validade e execução de contratos de qualquer natureza (pública ou privada), desde que por lei o contrato tenha sido ou devesse ter sido precedido de um procedimento pré-contratual regulado por normas de direito público.

Finalmente, por aplicação da alínea f) está subordinada à jurisdição arbitral qualquer questão respeitante a contratos administrativos, entendidos como os contratos administrativos típicos (aqueles cujo regime

12 O que significa reconhecer no âmbito das relações contratuais aquilo que é negado nas relações juridico-administrativas gerais: a anulação de actos administrativos por tribunais arbitrais - cfr. Pedro Gonçalves, O Contrato Administrativo (Uma instituição do direito administrativo do nosso tempo), Coimbra, 2003, pág. 170; MÁRIO AROSO DE Almeida, O Novo Regime do Processo nos Tribunais Administrativos, 4. ed., 2005. pág. 407, numa interpretação que elimina essa aparente contradição legislativa.

${ }^{13}$ Cfr. Mário Esteves de Oliveira / Rodrigo Esteves de Olrveira, Código de Processo nos Tribunais Administrativos, Estatuto dos Tribunais Administrativos e Fiscais, anotados, I, 2006, pág. 45 . 
substantivo se encontra regulado total ou parcialmente por normas de direito público no âmbito de uma relação jurídico-administrativa), os contratos cujo conteúdo (ou objecto, como prefere a lei) é susceptível de constituir o conteúdo de um acto administrativo, e os contratos que, embora possuam um conteúdo susceptível de ser objecto de um contrato de direito privado, foram pelas partes (uma das quais, pelo menos, seja entidade pública ou titular de poderes públicos) submetidos a um regime substantivo de direito administrativo ${ }^{14}$.

b) Responsabilidade civil extracontratual, incluindo a efectivação do direito de regresso, valendo aqui a lei substantiva que regula a matéria de responsabilidade da Administração Pública (o Decreto-Lei n. ${ }^{\circ}$ 48.051, de 21 de Novembro de 1967); porém, prevenindo a entrada em vigor de um novo regime jurídico sobre esta matéria, o legislador do CPTA exclui a responsabilidade decorrente do exercício da função política, legislativa e jurisdicional (cfr. art. $185^{\circ}$ ).

c) Actos administrativos que possam ser revogados sem fundamento na sua invalidade, nos termos da lei substantiva, ou seja, todos os enquadráveis no art $140{ }^{\circ}$ do Código de Procedimento Administrativo (CPA) e aqueles cuja revogabilidade decorre de lei especial.

Assim, poderão ser objecto de julgamento em tribunal arbitral todos os conflitos relacionados com os actos revogados ou com revogação projectada (nos casos em que haja cláusula compromissória ${ }^{15}$ ) com efeitos ex nunc por razões de adequação ao interesse público, ainda que dentro dos limites impostos pelo art. $140 .^{\circ}$ do CPA - e portanto apenas de actos discricionários, não constitutivos de direitos, ainda que quanto à determinação deste conceito não haja unanimidade na doutrina e jurisprudência (em todo o caso, parece claro que os actos de conteúdo desfavorável e os actos precários são susceptíveis de revogação).

A previsão constante desta última alínea suscita, aliás, duas considerações que não devemos omitir. A primeira prende-se com a evidenciação de que a invalidade dos actos administrativos não é matéria que esteja na disponibilidade da Administração e dos interessados, pelo que a resolução de um litígio que passe pela anulação de um acto administrativo só pode ser feita pelos tribunais administrativos ${ }^{16}$. Uma segunda ${ }^{14}$ Para mais desenvolvimentos, vide Pedro Gonçalves, O Contrato..., cit., págs. 57 e segs.
${ }^{15}$ Em sentido diferente, M. Aroso DE A Imeida, O Novo Regime...., cit., pág. 409 , nota 339.
${ }^{16}$ De acordo com a ideia ou princípio de que a questão da legalidade dos actos adminis-
trativos é uma questão de ordem pública - sobre este princípio e as leituras mais e 
nota, para destacar que o poder que é conferido aos tribunais arbitrais de proceder à revogação de actos por razões de interesse público pressupõe a limitação (ou auto-limitação) da discricionariedade administrativa - ao admitir-se que a Administração se sujeite a uma reapreciação do seu juízo de adequação do acto e do respectivo conteúdo ao interesse público - o que contende com a autonomia da função administrativa em relação à função de julgar ${ }^{17}$.

Refira-se ainda que, em qualquer das situações descritas no n. ${ }^{\circ} 1$ do art. $180 .^{\circ}$, caso existam contra-interessados, o litígio não pode ser dirimido por um tribunal arbitral, a não ser que aqueles aceitem tal compromisso - é solução imposta pelo $n .^{\circ} 2$ do art. $180 .^{\circ}$ do CPTA, que se justifica pela relevância da tutela dos interesses dos contra-interessados no âmbito das relações jurídico-administrativas (os quais deverão obrigatoriamente ser demandados por aplicação analógica do art. $57^{\circ}$ do CPTA; desta forma, havendo aceitação do compromisso, a decisão proferida faz caso julgado em relação a todos os intervenientes, em concretização do princípio da economia processual). De outro modo, o tribunal arbitral assumir-se-ia como um «feudo» do qual os eventuais contra-interessados seriam, à partida, exclüidos ${ }^{18}$.

\section{A lei especial ressalvada no $n .^{\circ} 1$ do art. $180 .^{\circ}$ do CPTA}

A primeira parte do $n .^{\circ} 1$ do art. $180 . .^{\circ}$ do CPTA admite o recurso à arbitragem sempre que haja lei especial a prevê-lo. É o que sucede, por exemplo, com a comissão arbitral criada para resolução de conflitos que surjam da aplicação dos regulamentos municipais de urbanização e ou

menos restritas da alínea c) do $n .^{\circ} 1$ do art. $1800^{\circ}$ do CPTA, pode ver-se M. ARoso DE Almeida, A arbitragem no direito administrativo portugués, in La contratación pública en el horizonte de la integración europea, V Congresso Luso-hispano de profesores de Derecho Administrativo, Madrid, 2004, págs. 95 e segs., maxime págs. 100 e segs.

No sentido de que alinea c) do $\mathrm{n} .^{\circ} 1$ do art. $1800^{\circ}$ permite que o tribunal arbitral se pronuncie sobre quaiquer questão, ainda que de validade ou de legalidade, relacionada com actos não constitutivos de direitos, por pertencerem à categoria dos actos revogáveis sem fundamento na sua invalidade, M. AROSO DE ALMEIDA, O Novo Regime..., cit., págs. 410 e 411.

${ }^{17}$ Neste sentido, José Llís Esquivel, Os Contratos Administrativos e a Arbitragem, 2004 , pág. 285.

18 Neste sentido, Mario Aroso de Almeida/ Carlos Fervandes Cadilha, Comentário ao Código de Processo nos Tribunais Administrativos, 2005, pág. 885. 
de edificação, dos regulamentos relativos ao lançamento e liquidação das taxas devidas pela realização de operações urbanísticas - arts. $118 .^{\circ} \mathrm{e}$ $3 .^{\circ}$ do Decreto-Lei 555/99, de 16 de Dezembro (na redacção que lhe foi dada pelo Decreto-Lei $177 / 2001$, de 4 de Junho). Também o art. $258 .^{\circ}$ do Decreto-Lei n. ${ }^{\circ} 59 / 99$, de 2 de Março (Regime Jurídico das Empreitadas de Obras Públicas), confere às partes a possibilidade de dirimir o conflito por via da arbitragem. É também o caso do tribunal arbitral criado para fixar a justa indemnização nas expropriações por utilidade pública (na falta de acordo entre as partes sobre o quantum indemnizatório ou tendo a expropriação natureza urgente - arts. 38. ${ }^{\circ}$ e segs. da Lei 168/99, de 18 de Setembro; da arbitragem constituída para fixar a indemnização e/ou os prejuízos decorrentes da implantação em prédios de linhas eléctricas - art 38. ${ }^{\circ}$ do Decreto-Lei 43.335, de 19 de Novembro de 1960; da arbitragem criada para fixar a indemnização pelos prejuizos decorrentes da constituição de servidão de gás ou para a implantação das infra-estruturas das concessões de serviço público relativas ao gás natural - art.17. da Lei 11/94, de 13 de Janeiro, da arbitragem constituída para dirimir litígios entre o titular de direitos telerisivos e demais operadores interessados na transmissão de um evento - art. $28 .^{\circ}$ da lei que regula 0 acesso à actividade de televisão e o seu exercício no território nacional (Lei $32 / 03$, de 22 de Agosto). Saliente-se que, nestas quatro situações, a arbitragem é inclusive obrigatória, ou seja. funciona como um tribunal arbitral necessário ${ }^{19}$.

Assim, conclui-se que, seja qual for a matéria em discussão (a qual pode ser diversa da indicada nas alíneas a) a c) do $n .^{\circ} 1$ do art. $1800^{\circ}$ do CPTA), a mesma será ainda susceptível de apreciação por um tribunal arbitral sempre que a lei expressamente o preveja ou se trate de litígio de natureza privada, e desde que as partes assim o convencionem (por via de uma cláusula compromissória ou compromisso arbitral). Não há, portanto, fundamento para excluir da jurisdição arbitral (jurídico-administrativa) determinadas questões de direito administrativo; ressalve-se apenas os conflitos que envolvam direitos indisponíveis, que a seguir consideraremos.

Podemos, por isso, afirmar que o âmbito de matérias eventualmente objecto de apreciação por um tribunal arbitral é muito mais abrangente

\footnotetext{
${ }^{19}$ No Ac. STJ de 2.12.1993, in BMJ 432. , pág. 289, entendeu-se até ser de aplicar a estes casos as regras da LAV.
} 
do que as três situações descritas no art. $1800^{\circ}$ do CPTA.

\section{A exclusão do âmbito da arbitragem dos direitos indisponíveis}

Como já referimos atrás, o art. $10^{\circ}$ da LAV proíbe a apreciação pelo tribunal arbitral de litígios que respeitem a direitos indisponíveis, isto é, direitos em relação aos quais não releva a vontade das partes. Em rigor, esta disposição não introduz qualquer novidade na nossa ordem jurídica, porquanto tradicionalmente tais direitos estão excluídos do âmbito desta jurisdição, quase se podendo afirmar um princípio de exclusão da jurisdição voluntária de questões relativas a direitos indisponíveis. Com efeito, tal exclusão já decorria do Código de Processo Civil de 1939 - art. $1562 .^{\circ}$ - e manteve-se no Código de Processo Civil de 1961 $-\operatorname{art.} 15100^{\circ} 20$.

Ora, poderá haver litígios, à partida enquadráveis nas alíneas a) a c) do $n .{ }^{\circ} 1$ do art. $180 .^{\circ}$ do CPTA, que envolvam direitos dessa natureza. Nesta hipótese, não pode deixar de se aplicar aqui o mesmo princípio ou proibição, por não se encontrarem razões que possam justificar a sua exclusão nas relações jurídico-administrativas. Na verdade, se há matérias de direito administrativo que estão, do ponto de vista substantivo, subtraídas à vontade das partes ${ }^{21}$, forçoso é proibir a estas últimas a obtenção dum resultado, que lhes está legalmente vedado, através de um processo indirecto de desistência do pedido ou da instância, da confissão ou de transacção judicial ${ }^{22}$ efectuado no âmbito de um conflito confiado a um tribunal arbitral.

Assim, conclui-se que o âmbito de jurisdição voluntária é simultaneamente mais abrangente e mais restrito do que o que parece resultar do disposto no art. $180 .^{\circ},{ }^{\circ} .^{\circ}$, do CPTA.

\footnotetext{
${ }^{20}$ Manifestando reservas quanto a esta solução, por não encontrar razões de fundo que justifiquem a subtracção de tais matérias à arbitragem, vide RALL VENTURA, in R.O.A., n. ${ }^{\circ} 48,1986$, II, pág. 321.

${ }^{21}$ Estamos a lembrar-nos, por exemplo, da renúncia antecipada e indiscriminada ao direito de indemnização consagrado no art. $22^{\circ}$ do Decreto-Lei 48051, de 21 de Novembro de 1967 , a qual deverá ser tida como nula por contrária à ordem pública (cfr. art. $2800^{\circ}$ do Código Civil).

${ }^{22}$ Cfr. Rodrigues Bastos, Notas ao Código de Processo Civil, II, 3. a ed., 2001, pág. 75.
} 


\section{O DIREITO À OUTORGA DO COMPROMISSO ARBITRAL}

\section{1. $O$ sentido da expressão «direito à outorga de compromisso arbitral»}

$\mathrm{O}$ art. $182 .^{\circ}$ sob a epígrafe direito à outorga de compromisso arbitral dispõe que o interessado que pretenda recorrer à arbitragem no âmbito dos litígios de natureza jurídico-administrativa - arts. $1800^{\circ}$ e segs. - pode exigir da administração a celebração de compromisso arbitral, nos termos da lei.

A questão que aqui se coloca é a de saber se o poder referido naquele preceito representa um direito potestativo ${ }^{23}$ que permita ao interessado, pela simples declaração dirigida à Administração, constituir esta no dever de celebrar o compromisso arbitral. Tal questão, que reveste de inegável interesse prático, quer para os particulares em geral quer para a Administração Pública, mereceu já a atenção da doutrina.

Segundo alguns autores, estamos perante um direito potestativo, por do seu exercício (unilateralmente) resultar a alteração da ordem jurídica $^{24}$. Uma tal perspectiva segue o sentido das propostas apresentadas antes da aprovação do CPTA e que pendiam para negar à Administração o poder de recusa do compromisso arbitral, como forma de incentivar o recurso à arbitragem ${ }^{25}$.

Para outros, não se pode ainda afirmar um direito à outorga do compromisso arbitral, ou pelo menos este não é ainda exercitável, uma vez que o próprio preceito, quando remete para «os termos da lei», faz depender a existência (ou a possibilidade de exercício) de tal direito de lei que especificamente venha regular os pressupostos da sua cons-

\footnotetext{
23 Por direito potestativo entende-se «o poder conferido a determinadas pessoas de introduzirem uma modificação na esfera juridica de outras pessoas (criando, modificando ou extinguindo direitos), sem a cooperação destas), JoÃo Avitunes Varela, Das Obrigações em Geral, 10. a ed, I, pág. 55.

24 Neste sentido, José Luís Esquível, Os Contratos ..., cit., págs. 260 e segs.

${ }^{25}$ Era o que resultava do Projecto do Código do Contencioso Administrativo de 1990 de Freitas do Amaral. Vide ainda Joào Martins Claro, A arbitragem no anteprojecto do Código de Processo nos Tribunais Administrativos, in CJA, n. ${ }^{\circ} 22$, págs. 83 e segs., maxime pág. 86, sugerindo a limitação de tal poder a determinadas matérias (especificamente às relações jurídicas administrativas paritárias).
} 
tituição ${ }^{26}$. Não nos parece, porém, que esta seja a melhor interpretação dessa remissão legal. Como já referimos, em outros pontos do regime jurídico da arbitragem o CPTA procede a remissões similares para a lei, que, na ausência de um diploma legislativo de direito administrativo sobre esta matéria, só pode ser a actual lei geral sobre arbitragem - a LAV -, nesta sede aplicável com as necessárias adaptações ${ }^{27}$. Aliás, como também já ficou referido, a necessidade de se proceder às devidas adaptações vem expressamente prevista no ${ }^{\circ} 1$ do art. $181 .^{\circ}$ do CPTA (procedendo o n. ${ }^{\circ} 2$ do mesmo preceito e do art. $1860^{\circ}$ do CPTA à concretização de algumas adaptações necessárias), o que só se explica por se tratar de uma remissão para a LAV, não fazendo sentido se se tivesse em vista uma futura lei que viesse regulamentar os casos omissos da arbitragem de conflitos de natureza jurídico-administrativa (de resto, uma e talvez a mais relevante adaptação é a da salvaguarda dos direitos dos contra-interessados, os quais deverão obrigatoriamente ser demandados por aplicação analógica do art. 57. ${ }^{\circ}$ do CPTA; desta forma, a decisão proferida faz caso julgado em relação a todos os intervenientes, em concretização do principio da economia processual). O facto de em alguns pontos o legislador remeter expressamente para a «lei sobre a arbitragem voluntária»e, neste ponto, se limitar a referir tão-só «nos termos da leì não nos parece ser um factor decisivo na interpretação do preceito ${ }^{28}$.

Mas há ainda quem rejeite ver no «poder de exigir» um direito po-

26 Neste sentido, M. Aroso De Aimeida, A arbitragem..., cit., pág. 116; M. ARoso DE Almeida / Carios Fervandes Cadilia, Comentório..., cit., págs. 891 e 892.

27 Especificamente, a aplicação da LAV tem de ser objecto de uma leitura adaptada ao disposto nos arts. $182 .^{\circ}$ a $184 .^{\circ}$ do CPTA, sobretudo quando se considere que os preceitos da LAV pressupōem a existência prévia de um compromisso arbitral ao contrário do que sucede naquelas disposições do CPTA - precisamente por isso, alguns autores rejeitam que a remissão legal do art. $182{ }^{\circ}$ do CPTA seja feita para LAV (neste sentido, entre outros, Pedro Govçalves, O Contrato ..., cit., pág. 169).

28 Demonstração da irrelevância da expressão empregue pelo legislador encontra-se a propósito da possibilidade de criação de centros de arbitragem, prevista no art. 187. - do CPTA, onde se remete também para os «termos da lei»; ora, aqui os mesmos autores que interpretam tal expressão legal como reportando-se a lei futura e especial no contexto do art. $182 .^{\circ}$ admitem, no âmbito do art. $187 .^{\circ}$, que essa possa corresponder aos diplomas normativos já existentes sobre a instalação e regulação dos centros de arbitragem - cfr. M. Aroso de Almeida Carlos Fervaldes Cadilha, Comentário..., cit., pág. 899 . 
testativo, independentemente da questão da interpretação da parte final do art. $182 .^{\circ}$ do CPTA. Assim, João Caupers defende que este preceito não confere um verdadeiro direito potestativo ao interessado, por a lei não prever efeitos jurídicos automáticos da recusa de celebrar o compromisso arbitral. E invoca ainda, para reforçar a inexistência de tal direito, o disposto no art. $183 .^{\circ}$ do CPTA, que, nas palavras do autor, "[...] é a prova de que o direito de requerer a arbitragem não é um direito potestativo: ao determinar a suspensão dos prazos para recorrer à jurisdição administrativa, o legislador admitiu, implicitamente, que o requerimento poderia nâo ser despachado favoravelmentes, ${ }^{29}$.

Também nós entendemos que tal poder de exigir não pode configurar um verdadeiro direito potestativo. Uma outra interpretação importaria resultados desproporcionados e injustos e até de constitucionalidade duvidosa, como o demonstra o seguinte exemplo: no âmbito de um contrato de empreitada estabelecido entre uma empresa de construçào civil, com significativo poder económico e financeiro, e uma Junta de Freguesia do interior do país, é por aquela exigido a esta a celebração de compromisso arbitral tendo por objecto questões relacionadas com a execução de um contrato de empreitada da instalação de saneamento. A empresa, investida de forte poder económico, contrata juristas especialistas na matéria de arbitragem, sem estar condicionada pelos (elevados) encargos que a constituição de um tribunal arbitral acarreta. Sendo evidente a significativa desproporção entre os recursos económicos das partes, será defensável que a Junta de Freguesia, parte mais «fraca» do ponto de vista financeiro, esteja obrigada a celebrar o compromisso arbitral?

É que a acentuada desigualdade financeira entre as partes poderá ter implicações no plano da efectivação da justiça. Na realidade, a insuficiência de meios económicos repercutir-se-á em todos os encargos decorrentes da arbitragem, nos quais se inclui a contratação de juristas, com potenciais reflexos negativos na intervenção formal e processual; isto, a admitir-se estar a parte administrativa vinculada a celebrar o compromisso arbitral.

Para minorar tal resultado, e por imposição do art. $20 .^{\circ}$ da Constituição da Republica Portuguesa, de modo a garantir à parte administrativa a defesa das suas posições juridicas subjectivas, apesar da sua

${ }^{29}$ A arbitragem na nova justiça administrativa, in CJA, n. ${ }^{\circ} 34$, pág. 66. 
eventual incapacidade financeira, poderia admitir-se a possibilidade de esta recorrer ao apoio judiciário. Simplesmente, a lei do apoio judiciário não tem aplicação na jurisdição arbitral voluntária ${ }^{30}$, pois a mesma tem o seu campo de acção limitado aos tribunais judiciais previstos na respectiva lei orgânica, não sendo aplicável aos tribunais arbitrais (os quais como se mencionou, têm natureza privada). De resto, considerando que à arbitragem regulada no CPTA se aplica o disposto no art. 5. ${ }^{\circ}$ da $\mathrm{LAV}^{31}$, nos termos do qual «[a] remuneraçâo dos árbitros e dos outros intervenientes no processo, bem como a sua repartição entre as partes, deve ser fixada na convenção de arbitragem ou em documento posterior subscrito pelas partes, a menos que decorra dos regulamentos de arbitragem escolhidos nos termos do art. $15^{\circ}$ " e, por um argumento de identidade de razão, a lei do apoio judiciário também não poderá ser aplicada aos conflitos jurídico-administrativos submetidos a um tribunal arbitral. Razão por que entendemos ser legítimo que a Administração recuse o recurso à arbitragem, designadamente com fundamento na insuficiência de verba; neste caso, abrir-se-ão as portas para o acesso aos tribunais administrativos.

Além do mais, um suposto estado de sujeição da parte administrativa, a existir, violaria os princípios da igualdade entre as partes, da proporcionalidade e da justiça também por permitir ao particular interessado impor à Administração, unilateralmente, a adopção de uma conduta, in casu a celebração do compromisso arbitral, o que conduziria a uma hierarquização da vontade e posição das partes, remetendo a da Administração para um patamar, inexplicavelmente, inferior.

${ }^{30}$ Neste sentido, entre outros, Salvador DA Costa, Apoio Judiciário, 2. ${ }^{a}$ ed., págs. 120 e segs; Ac. STJ, in BMJ 493., pág. 327; Ac. RL, in CJ, 2001, III, pág.110.

${ }^{31}$ Quanto à questão dos encargos processuais no âmbito da arbitragem prevista no CPTA, este diploma nada dispõe, contrariamente ao que sucede na LAV, pelo que neste domínio será de aplicar o disposto no art. 5. desta lei. Não é crível que o legislador tenha olvidado matéria tão sensível quanto esta que, mais das vezes, é determinante para as partes optarem pelos tribunais judiciais ou arbitrais; não sendo despiciendo afirmar que é justamente a insuficiência de meios financeiros a maior desvantagem da arbitragem. Ora, o problema que se levanta neste domínio é o de saber em que moldes serão fixados os honorários dos árbitros e a sua forma de repartição nas arbitragens previstas no CPTA. Para quem interprete a exigibilidade no sentido de um direito potestativo, parece que caberia ao interessado, ao requerer a outorga do compromisso arbitral, estabelecer a regras de funcionamento do tribunal onde se incluiria o modo de repartição dos encargos; tal solução não nos parece, porém, razoável nem exequível. 
O entendimento por nós sufragado é ainda reforçado pelo conteúdo dos arts. $183 .^{\circ}$ e $184 .^{\circ}$ do CPTA. Na verdade, a indicação de que o poder de exigir a celebração do compromisso arbitral é feito mediante requerimento, o qual vai ser objecto de decisão (ou despacho) administrativa, indicia claramente não se tratar de um direito potestativo, mas antes de uma pretensão que vai ser apreciada pela Administração. Parece-nos, com efeito, haver uma contradição insanável com a definição de direito potestativo e a necessidade de um despacho ou acto promovido pelo Ministro da tutela destinado a conferir eficácia prática à pretensão do interessado. Não faria sentido o legislador conceder ao interessado um verdadeiro direito potestativo de recurso à arbitragem, fazendo depois depender a sua eficácia ou efectividade de um despacho a emitir pelo Ministro da tutela (ou por outro órgão, no caso das restantes pessoas colectivas públicas).

Interpretar esta disposição em concordância com o direito potestativo de aceder à arbitragem implicaria ver neste despacho um acto totalmente vinculado à lei, ou uma mera notificação de determinado facto já consumado, conclusão que não resulta do teor do art. $184 .^{\circ}$ do CPTA, mesmo abrindo de forma manifesta a letra do preceito ${ }^{32}$. Que tal despacho não tem conteúdo vinculado resulta, como se infere do argumento avançado por Caupers retirado do disposto no art. $183 .^{\circ}$ do CPTA: a previsão legal de que a apresentação do mencionado requerimento suspende os prazos para recorrer aos meios processuais próprios da jurisdição administrativa implica ou pressupõe o reconhecimento de que o requerimento pode ser objecto de despacho de recusa ${ }^{3 \hat{3}}$.

Em síntese, o «direito» à outorga do compromisso arbitral não corresponde a um direito potestativo, tratando-se antes de uma mera pretensão à celebração do compromisso arbitral.

\footnotetext{
32 Segundo M. Aroso de Almeida/ Carlos Fernaides Cadilha, Comentário..., cit., pág. 894 , o âmbito de aplicação do art. $184{ }^{\circ}$ restringe-se aos casos não abrangidos pelo art. $182 .^{\circ}$. Não podemos concordar com os autores quando sustentam que a compatibilização do disposto no art. $182 .^{\circ}$ e o que determina o art. $184 .^{\circ}$ se alcança pela interpretação restritiva do art. $184 .^{\circ}$ - em nosso entender é o poder de exigir do art. $182 .^{\circ}$ que tem de ser interpretado restritivamente, por força do disposto nos arts. $183 .^{\circ}$ e $184 .^{\circ}$.

33 Permitimo-nos acrescentar que a interpretação deste artigo levada às últimas consequências possibilita ainda à parte com maior poder económico encontrar na «exigência» do art. $182 .^{\circ}$ uma forma hábil de lançar mão de um expediente legal - art. 183. CPTA - com intuitos meramente dilatórios, como seja a suspensão de prazos em curso potencialmente geradores de, por exemplo, mora ou incumprimento contratual.
} 


\section{Consequências da recusa da outorga do compromisso arbitral}

Esclarecido que a Administração tem o poder de outorgar ou não o compromisso arbitral requerido pelo interessado, impõe-se agora ponderar as consequências de um eventual despacho de recusa de outorga daquele.

Ora, requerendo o interessado a celebração do compromisso arbitral, fica a Administração constituída no dever de decisão, no prazo legal de 30 dias. A pronúncia da Administração constitui um verdadeiro acto administrativo, ou seja, um acto jurídico emitido pela Administração, no âmbito dos seus poderes de autoridade, que contém uma decisão dirigida a produzir efeitos num caso concreto e individual, sujeito à disciplina dos arts. $1200^{\circ}$ e segs. do CPA ${ }^{j 4}$. Já que contém uma definição jurídica sobre a pretensão do interessado à outorga de um concreto compromisso arbitral, nessa medida perfeitamente individualizada e concreta, resta apenas compreender em que medida o despacho envolve alguma dose de discricionariedade.

A este propósito importa distinguir entre a emissão do despacho e o seu contelido:

a) Em relação à emissão do despacho, independentemente da faculdade da Administração de outorgar ou não o compromisso arbitral, está claramente em causa um poder vinculado, por se tratar de uma estrita aplicação da lei a um caso individual e concreto; por outras palavras, o art. $184 .^{\circ}$ do CPTA impõe à Administração o poder-dever de emitir o despacho no prazo de 30 dias, contado desde a apresentação do requerimento do interessado.

b) Ao invés, quanto ao conteúdo do despacho, o órgão administrativo competente deverá exará-lo, com base e no respeito pela lei, mas com discricionariedade: portanto, de acordo com os critérios que entenda mais adequados à prossecução do interesse público. Pode assim recusar a pretensão do particular, ou optar por sujeitar o litígio à arbitragem; nesta última hipótese, pode limitar-se a concordar em outorgar o compromisso arbitral ou pode ainda consignar no despacho de forma expressa e especificada quais os aspectos processuais e de funciona-

34 Sobre o conceito de acto administrativo, vide. entre outros, ROGÉRIO E. SOARES, Direito Administrativo (Lições), 1978, pág. 76; Diogo Freitas do Amaral, Curso de Direito Administrativo, Vol. II, 2002, pág. 233; PIREs MACHAdo, O acto administrativo. in Contencioso Ad́ministrativo, 1986, págs. 71 e segs., em especial pág. 89. 
mento do tribunal arbitral a que o litígio ficará submetido (de resto, à semelhança do prescrito na LAV - arts. $15 .^{\circ}$ e ss.)

\section{Natureza jurídica do compromisso arbitral}

Aqui chegados, resta-nos apenas concluir acerca da natureza jurídica do compromisso arbitral.

Referimos já que do disposto no art. $10^{\circ}$ da LAV decorre possuir o compromisso arbitral natureza convencional: são as partes quem, através da celebração de uma convenção de arbitragem, atribui poderes aos árbitros para que estes dirimam os litígios que lhes são submetidos. A mesma natureza possui a cláusula compromissória, nos termos preceituados no n. ${ }^{\circ} 2$ do mesmo artigo.

Qualquer litígio submetido ao tribunal arbitral depende da vontade das partes expressa nessa convenção de arbitragem, modificativa da competência atribuída aos tribunais comuns. A convenção de arbitragem deve, ainda, determinar com precisão o objecto do litígio (compromisso arbitral) ou especificar a relação jurídica a que os litígios respeitem (cláusula compromissória). Do exposto, e como se tem entendido, no âmbito da LAV está-se em presença de um contrato. Mas será que o carácter jurídico-administrativo dos litígios altera essa natureza, no caso do compromisso arbitral constante do art. $182 .^{\circ}$ do CPTA?

$\mathrm{Na}$ nossa perspectiva, o compromisso arbitral não pode deixar de ser entendido similarmente, como um contrato estabelecido entre o interessado e a Administração. Com efeito, e como se expôs atrás, a Administração, no uso do seu poder discricionário, pode recusar a outorga do compromisso arbitral ou outorgar o mesmo. No primeiro caso, o problema não se chega a colocar, mas nesta última hipótese há que promover a constituição do respectivo tribunal e determinar as regras do seu funcionamento como prescreve o ${ }^{\circ}{ }^{\circ} 1$ do art. $181 .^{\circ}$ do CPTA, que remete, com as devidas adaptações, para a LAV. E terão de ser de estabelecidas as regras de funcionamento da arbitragem, as quais podem ficar consagradas, justamente, no compromisso arbitral; ora, este mais não é, ou pode não ser mais, do que o requerimento do interessado mencionado no n. ${ }^{\circ} 1$ in fine do art. $184 .^{\circ}$ do CPTA, em observância do n. 2 do art. $2 .^{\circ}$ da LAV. Isto porque, como se explicou supra, sendo o CPTA omisso quanto a este aspecto, aplica-se supletivamente a LAV. 
Ora, perante o requerimento que lhe é dirigido, a Administração, se pretende outorgar o compromisso arbitral, ou aceita os termos do mesmo ou discute-os até ser atingida uma plataforma consensual.

Em qualquer dos casos, a convergência de vontades do interessado e da Administração revela-se imprescindivel para a outorga do compromisso arbitral, nisto se revelando a sua natureza convencional. Deste modo, pode definir-se o compromisso arbitral como um contrato e, nessa medida, uma vez formalizado, vinculativo para as partes.

Questão pertinente é ainda a de saber como pode o interessado reagir na hipótese de a Administração, apesar de constituída no dever de emanar um despacho sobre o requerimento do interessado, não o fazer dentro do prazo legalmente estabelecido. Ou ainda no caso de emitir um acto expresso de recusa do compromisso arbitral. Face à a aplicação supletiva da LAV, o interessado, perante o silêncio ou recusa da Administração e partindo do princípio que as regras de funcionamento da arbitragem constam do requerimento por si apresentado, pode requerer, ao abrigo do disposto no $\mathrm{n}^{\circ} 2$ do art. $181^{\circ}$ do CPTA, ao Tribunal Central Administrativo do lugar fixado para a arbitragem e ao respectivo Presidente a nomeação dos árbitros para dirimir o litígio, em consonância com o disposto na al. c) do ${ }^{\circ} .^{\circ} 1$ do art. $36 .^{\circ}$ do ETAF e no art. $12 .^{\circ}$ da $\mathrm{LAV}^{35}$.

Ao invés, para quem entenda que a exigência representa um direito de natureza potestativa, não tendo sido emitido o despacho a que alude o art. $184 .^{\circ}$ do CPTA, poderá o interessado lançar mão da acção administrativa para condenação da administração à prática do acto legalmente devido - al. b) do $n .^{\circ} 2$ do art. $46 .{ }^{\circ}$ do CPTA.

\section{Síntese conclusiva}

Em síntese, das palavras que temos vindo a produzir fica a ideia de que o poder contido no art. $182 .^{\circ}$ do CPTA se reporta à pronúncia da entidade administrativa competente, pela qual esta aceita ou recusa a outorga do compromisso arbitral, fundamentando circunstanciadamente tal decisão.

A Administração veicula a posição assumida através do despacho que deverá emitir no prazo legal de 30 dias - art. $184 .^{\circ}$ do CPTA -,

${ }^{35}$ No mesmo sentido, José Luis Esquivel, Os contratos Administrativos..., cit. pág. 263. 
sendo este um verdadeiro acto administrativo vinculado, quanto à sua emissão, mas discricionário quanto ao seu conteúdo.

Face ao silêncio da administração, aplicar-se-á a título supletivo o disposto na LAV (assumindo, neste contexto, especial relevância as considerações inicialmente produzidas sobre essa aplicação), podendo o interessado requerer a nomeação de árbitros ao abrigo do art. $12 .^{\circ} \mathrm{da}$ LAV e da al. c) do n. ${ }^{\circ} 1$ do art. $36 .^{\circ}$ do ETAF. 